\title{
PENYULUH AGAMA ISLAM, RELIGIUSITAS, DAN SALATIGA SEBAGAI KOTA TOLERAN
}

\author{
Sholahuddin'1, Zaenal Abidin Eko Putro² \\ 1Puslitbang Bimas Agama dan Layanan Keagamaan, Badan Litbang dan Diklat Kementerian Agama \\ ${ }^{2}$ Politeknik Negeri Jakarta \& Centre of Asian Studies (CENAS)

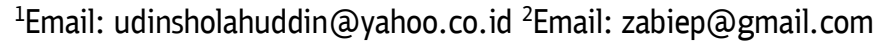

\author{
https://doi.org/10.36052/andragogi.v8i2.163 \\ Diterima: 03 September 2020 | Disetujui: 10 Desember 2020 | Dipublikasikan: 26 Desember 2020
}

\begin{abstract}
Abstrak
Dalam aspek pengembangan serta penguatan religiusitas masyarakat, peran penyuluh agama Islam yang berada di bawah Kementerian Agama, termasuk untuk wilayah Kota Salatiga, hampir tidak dapat dielakkan. Tugas mereka secara rinci telah dirilis, yaitu sesuai Surat Keputusan Direktur Jenderal Bimbingan Masyarakat Islam No. 298 Tahun 2017 tentang Pedoman Penyuluh Agama Islam Non PNS yaitu sebanyak 8 (delapan) bidang yang diidealkan melekat pada kepenyuluhan. Kedelapan spesialisasi itu antara lain adalah Baca Tulis Alquran (BTA), produk halal, radikalisme dan aliran sempalan, keluarga sakinah, HIV/AIDS \& Narkoba, Zakat, Wakaf, dan Kerukunan Umat Beragama (KUB). Di samping itu, telah menjadi rahasia umum, bahwa Salatiga beberapa tahun ini tergolong kota paling toleran versi Setara Institute. Akan tetapi, bagaimana kiprah para penyuluh agama dalam memenuhi delapan dimensi tersebut serta menyeleraskan pada predikat kota toleran itu sejauh ini masih belum banyak dipublikasikan. Artikel dari hasil penelitian kualitatif ini berusaha memberi gambaran bagaimana para penyuluh Agama Islam di wilayah Salatiga itu mampu memainkan perannya dalam memenuhi delapan dimensi kerja, sekaligus memperkuat religiusitas dan harmoni di tengah masyarakat Salatiga yang plural walaupun menghadapi beberapa tantangan.
\end{abstract}

Kata Kunci: Penyuluh Islam, delapan spesialisasi, kota toleran, religius

\begin{abstract}
[COUNSELERS OF ISLAMIC RELIGION, RELIGIUSITY, AND SALATIGA AS A TOLERANT CITY]. Developing and strengthening religiously motivated society lies on the responsibility of the Islamic religious instructors including those who works for the Ministry of Religious Affairs (MoRA) of Salatiga City, Central Java. Their detailed tasks have been released, that is in accordance with the Decree of the Director General of Islamic Community Guidance No. 298 of 2017 concerning Guidelines for Islamic Extension Workers, namely 8 (eight) specific fields which are the following; Read and Write the Qur'an, halal products, radicalism and Islamic splinter group, sakinah families, HIV/AIDS \& Drugs, Zakat, Waqf, and Religious Harmony. In addition, it is widely known that Salatiga has been granted as the most tolerant city in Indonesia by the Setara Institute for the last several years. Currently, the role of religious instructors to fulfill their assignments to support such tolerant city remains less unknown. This article that is stemmed from the qualitative research has shown that religious instructors of Islam section in Salatiga are able to fulfill their role as the contributor for religiosity and harmony in society, although some challenges are remain. They could also accelerate with the title of tolerant city that pinned to their city.
\end{abstract}

Keywords: Islamic Instructor, eight specialties, tolerant city, religiosity

This work is licensed under a Creative Commons Attribution-NonCommercial 4.0 International License 


\section{PENDAHULUAN}<smiles>[Mg]</smiles>
asyarakat Indonesia adalah masyarakat religius. Sila Pertama Pancasila memberi landasan bahwa masyarakat Indonesia sangat dekat dengan nilai-nilai religius, dan pemahaman ini mengarah pada pandangan humanistic berdasarkan nilai-nilai Pancasila yang telah lama digulirkan lewat pendidikan (Usman et al., 2017: 109).

Religiusitas masyarakat Indonesia yang menjadi basis ekstraksi nilai menjadi butir Sila Pertama dalam Pancasila telah diperjuangkan para Bapak Bangsa menjadi landasan negara. Cukup dimaklumi jika hingga pada akhirnya sampailah pada penilaian tentang kecenderungan masyarakat Indonesia yang bertautan erat dengan wilayah dan hal-hal berbau keagamaan. Meminjam istilah Jeremy Menchik, begitu dekatnya masyarakat Indonesia dengan hal-hal yang berbau agama, dalam hal nasionalisme pun disebutkan Menchik sebagai Godly nationalism yang diadaptasi dari imagined community-nya Ben Anderson. Secara pendek, pengertian Godly nationalismnya Menchik ialah ...an imagined community bound by a common, orthodox theism and mobilized through the state in cooperation with religious organizations in society (Menchik, 2014: 594). Di sini Menchik menguraikan nationalism di Indonesia yang digambarkan sebagai masyarakat terbayangkan yang diikat oleh kesamaan paham ketuhanan dan dimobilisasi melalui negara melalui kerjasamanya dengan organisasi-organisasi agama di masyarakat.

Setidaknya terdapat lima macam dimensi religiusitas menurut Glock dan Stark (Salleh, 2012: 268), yaitu ; dimensi keyakinan (religious belief), dimensi peribadatan atau praktek agama (religious practice), dimensi pengalaman keagamaan (religious feeling), dimensi intelektual dan pengetahuan agama (religious knowledge), serta dimensi penerapan (religious effect). Kelima dimensi religiusitas tersebut jika digunakan untuk melihat religiusitas masyarakat Indonesia akan banyak menemukan keselarasan. Ramainya tempat ibadah, maraknya aksi-aksi yang dimotivasi agama, termasuk infiltrasi terhadap budaya populer sangat mudah ditemukan pada masyarakat Indonesia dewasa ini.

Dalam koridor ini, religiusitas masyarakat yang tergambarkan dalam dimensi-dimensi itu sejauh ini tentunya juga menjadi kesadaran dan pengetahuan bagi pihak-pihak yang secara langsung berhubungan dengan penguatan religiusitas di masayarakat, yang salah satu pihak tersebut adalah para penyuluh Agama di bawah Kementerian Agama, khususnya penyuluh Agama Islam. Dikaitkan dengan tugas pokok dan fungsi (tupoksi) para Penyuluh Agama Islam, definisi dan urgensi religiusitas Stark \& Glock di atas menemukan relevansinya.

Allport and Ross (1967) membagi religiusias ke dalam dua bidang yaitu ekstrinsik (self-serving and utilitarian outlook) dan intrinsik (internalizes the total creed of his or her faith) dan juga Fukuyama (1960) membagi empat dimensi religiusitas yaitu cognitive, cultic, creedal, and devotional (Holdcroft, 2006: 90). Pada intinya, dimensi-dimensi tersebut menunjukkan adanya kedekatan seseorang dan juga pengetahuan, pengalaman dan sikap seseorang tersebut dengan agamanya, untuk dikategorikan religius.

Lebih jauh, urgensi religiusitas dalam perkembangan masyarakat, selanjutnya dapat ditemukan titik temunya dalam uraian Bergan and McConatha (2000) yang menyebutkan adanya relasi positif antara religiusitas dan kebahagiaan. Keduanya melakukan studi terhadap kelompok remaja, dewasa dan manula di Amerika. Disimpulkan bahwa studi yang menguji tentang religiusitas dan kepuasan hidup (life satisfaction) pada tiga kelompok usia tersebut menyebutkan bahwa orang yang mengekspresikan dan terlibat secara kuat dalam bidang keagamaan, kecil kemungkinan dilanda stress dan lebih besar peluang atas kepuasan hidupnya. Afiliasi pada beragam hal tentang keagamaan menjadi pengukur signifikan untuk kepuasan hidup secara umum, serta rasa memiliki dan kejelasan tujuan dalam hidup (Holdcroft, 2006: 93)

Religiusitas masyarakat Indonesia, yang diekstraksi menjadi sila pertama Pancasila, dapat terbaca dalam batas-batas tertentu dapat menyeruai fenomena kebangkitan agama (religious revivalism) dalam analisis Gopin (2000) (Olomojobi, 2017). Menurutnya, 
kebangkitan agama ini dapat mengarah pada harmoni di masyarakat. Kebangkitan agama ini dapat membangkitkan perasaan kekuatan ikatan akan sesama pemeluk agama (coreligionist) yang membawa pada gerak maju dan harmoni di masyarakat. Namun begitu, Gopin juga melihat kemungkin lain dari religious revivalism ini, yaitu membahwa pada ketegangan dan konflik dengan penganut agama lain.

Sejauh ini, perwujudan religiustas di masyarakat Muslim Indonesia paling mudah ditelisik dari berlangsungnya proses pengajaran Agama Islam pada masyarakat Muslim di Indonesia. Selain dilakukan secara mandiri berdasarkan inisiatif masyarakat, pengajaran Agama Islam terseut juga difasilitasi oleh negara, yang dikoordinasi di bawah Kementerian Agama (Kemenag) RI. Untuk yang terakhir ini dibuktikan dengan diangkatnya para penyuluh agama, baik berstatus PNS maupun Non PNS.

Penyuluh agama, seperti tercantum dalam Keputusan Menteri Agama RI Nomor 791 tahun 1985, adalah bertugas sebagai pembimbing umat beragama dalam rangka pembinaan mental, moral dan ketaqwaan kepada Tuhan Yang maha Esa. Dengan demikian, penyuluh Agama Islam adalah pembimbing umat Islam dalam rangka pembinaan mental, moral dan ketaqwaan kepada Allah SWT, serta menjabarkan segala aspek pembangunan melalui unsur dan bahasa agama (Kusnawan, 2011: 276).

Selanjutnya, Keputusan Bersama Menteri Agama RI dan Kepala Badan Kepegawaian Negara Nomor 574 tahun 1999 dan nomor 178 tahun 1999 tentang Jabatan Fungsional Penyuluh Agama dan Angka Kreditnya menyebutkan fungsi penyuluh agama yang meliputi tiga fungsi, yaitu informatif dan edukatif konsultatif, dan ketiga fungsi administratif. Apabila dicermati, ketiga fungsi tersebut menjadi kepanjangan tangan dari program pembangunan di bidang sumber daya manusia (SDM) pada masyarakat Muslim secara luas yang digulirkan pemerintah. Dilihat dari ketiga fungsi tersebut, terutama fungsi pertama dan kedua, tersirat jelas tuntutan peran Penyuluh Agama Islam untuk ikut mewujudkan kondisi masyarakat yang religius yang memahami ajaran agamanya, serta memahami kondisi masyarakatnya.

Legalitas Penyuluh Agama Non PNS belakangan baru diperkuat didasarkan atas Keputusan Menteri Agama (KMA) Nomor 148 Tahun 2014 tentang Penetapan Honorarium bagi Penyuluh agama non Pegawai Negeri Sipil (Aliyah \& Kusuma, 2019; Noorbani, 2013). Umumnya, mereka merupakan para guru agama atau penceramah (dai) mandiri yang telah lama melayani kebutuhan ruhani masyarakat, sebelum kemudian lolos seleksi. Namun terkadang, status penyuluh agama di bawah Kemenag tidak tampak dan masih di bawah bayang-bayang peranan individu maupun lembaga tradisi dan lembaga bentukan pemerintah yang lain seperti Forum Kerukunan Umat Beragama (FKUB) (Syuhudi, 2017).

Untuk memantapkan kinerja penyuluh agama (Islam) yang berstatus Non PNS, melalui Surat Keputusan Direktur Jenderal Bimbingan Masyarakat Islam No. 298 Tahun 2017 (Surat Keputusan Direktur Jenderal Bimbingan Masyarakat Islam No. 298 Tahun 2017 tentang Pedoman Penyuluh Agama Islam Non PNS.pdf, n.d.) tentang Pedoman Penyuluh Agama Islam Non PNS, telah dijabarkan spesialisasi ruang kerja dan isu-isu yaitu sebanyak 8 (delapan) bidang yang diidealkan melekat pada kinerja kepenyuluhan untuk kalangan penyuluh non PNS. Kedelapan spesialisasi itu antara lain adalah Baca Tulis Alquran (BTA), produk halal, radikalisme dan aliran sempalan, keluarga sakinah, HIV/AIDS \& Narkoba, Zakat, Wakaf, dan Kerukunan Umat Beragama (KUB).

Beberapa publikasi sebelumnya yang membahas kinerja penyuluh agama Islam menyebut beberapa hal, antara lain tentang aspek legalitas, status dan kelayakan penyuluh agama Islam serta wilayah kerja dan urgensi kepenyuluhan Agama Islam (Aliyah \& Kusuma, 2019; Basit, 2014; Ilham, 2018; Noorbani, 2013). Akan tetapi, beberapa tulisan tersebut belum spesifik menyinggung pemenuhan kinerja penyuluh agama Islam non PNS tentang delapan dimensi spesialisasi kerja penyuluh agama Islam non PNS dan kemudian dikaitkan dengan aspek religiusitas masyarakat.

Dengan demikian, artikel tentang penyuluh agama Islam di kota Salatiga, Jawa Tengah belum banyak dilakukan. Satu dari yang sedikit 
itu adalah artikel Mawardi (Mawardi, 2017) yang menuliskan peran penyuluh agama Islam di Salatiga dengan upaya penguatan dimensi keluarga Sakinah. Penelitiannya lebih menitikberatkan pada kinerja kepenyuluhan akan pentingnya keluarga sakinah di satu kecamatan di Salatiga. Hampir terdapat kemiripan, penyuluh Agama dan peranannya dalam penguatan keluarga sakinah juga ditulis Rosidin (Rosidin, 2017) yang menjelaskan peran penyuluh agama Islam dalam membina keluarga majlis taklim di Sragen, Jawa Tengah.

Menitikberatkan Salatiga dalam tulisan ini karena didorong beberapa hal, antara lain Salatiga beberapa tahun (2016-2017) dinobatkan di antara kota paling toleran versi Setara Institute (Munir, 2017). Baru tahun 2018 lalu Kota ini bertengger di urutan nomor dua setelah Kota Singkawang, Kalimantan Barat. Alasan berikutnya, karena Kota Salatiga juga secara demografis dihuni oleh masyarakat dari berbagai latar belakang agama dan suku. Keragaman itu tercermin dari banyaknya rumah ibadah, selain rumah ibadah Islam, yang dapat ditemukan di beberapa pelosok wilayah di kota ini.

Meski secara garis besar menyoroti pemenuhan delapan spesialisasi penyuluhan agama Islam itu secara khusus di Salatiga, artikel ini juga dimaksudkan untuk memberi gambaran peran penyuluh agama Islam, terkait keunikan kota Salatiga yang dikenal toleran. Tulisan ini juga ingin melihat pada aspek yang lebih deskriptif tentang upaya pemenuhan kinerja yang meliputi kinerja penyuluh berdasarkan delapan spesialisasi, seperti telah disinggung di atas.

\section{METODE PENELITIAN}

Tulisan ini dihasilkan dari penelitian dengan menggunakan metode kualitatif. Berlandaskan pilihan metode penelitian ini, untuk menggali kedalaman informasi dan juga natural world subjek yang diteliti (Aspers \& Corte, 2019; Mohajan, 2018), penulis melakukan penggalian data dengan cara mengunjungi lokasi penelitian dan melakukan observasi serta wawancara mendalam dengan pihak-pihak yang telah ditentukan menjadi informan. Kerja lapangan (field work) dilakukan pada Bulan Oktober 2019 di Salatiga.

Pilihan dan penunjukan informan sesuai kategori sample dilakukan dengan cara snow balling, yaitu mengikuti saran dan rekomendasi dari informan kunci, dilanjutkan kepada informan yang ditunjuk oleh informan kunci. Karena terkait dengan kinerja penyuluh di lingkungan Kementerian Agama di wilayah tingkat dua, maka penulis langsung menargetkan Ketua Pokjaluh Kementerian Agama Kota Salatiga sebagai informan kunci.

Setelah bertemu dan menggali informasi dari Ketua Pokjaluh Agama Islam Kementerian Agama Salatiga, penulis selanjutnya diarahkan untuk bertemu dengan kalangan berwenang di Kementerian Agama Salatiga, Seksi Bimas Islam, Kabag TU dan tentu saja para penyuluh yang telah dilihat kapasitasnya terutama terkait dengan delapan spesialiasi tema kepenyuluhan tersebut di atas. Selanjutnya penulis menemui penyuluh-penyuluh Agama Islam non PNS di dua Kecamatan, yaitu Kecamatan Argomulyo dan Kecamatan Sidorejo. Selain itu, penulis juga menggali informasi dari masyarakat yang menjadi jamaah kepenyuluhan (pengajian) penyuluh-penyuluh tersebut. Beberapa kali pula penulis mengikuti kegiatan kepenyuluhan para penyuluh agama Islam tersebut di dua kecamatan tersebut.

Analisis data dilakukan secara deskriptif dengan cara setelah data terkumpul, kemudian direduksikan dengan cara mendialogkan antardata, kemudian data tersebut didisplay dan selanjutnya diverifikasi untuk kemudian dapat ditarik kesimpulan (Sugiono, 2014).

\section{HASIL DAN PEMBAHASAN}

Salatiga dikenal plural dan toleran, sebagaimana hasil yang dirilis Setara Institute. Di kalangan peyuluh Agama Islam non PNS, predikat ini sangat diketahui, bahkan menurut mereka hampir seluruh masyarakat Salatiga mengetahui akan predikat tersebut. Pimpinan pemerintah kota pun turut mempopulerkan penganugerahan predikat tersebut, hingga diliput media secara luas. Begitu pun, berdasarkan oberservasi singkat lapangan juga terkonfirmasi mudahnya dijumpai orang lalu lalang di pusat kota, Jalan Sudirman, yang 
memiliki pelbagai ciri wajah, misalnya Melayu Jawa, Tionghoa (mongoloid) dan Indonesia timur (milanesia).

Tabel. Penduduk Salatiga berdasarkan agama

\begin{tabular}{llr}
\hline No. & \multicolumn{1}{c}{ Agama } & \multicolumn{1}{c}{ Jumlah } \\
\hline 1. & Islam & 152.834 \\
2. & Kristen & 31.776 \\
3. & Katolik & 9.475 \\
4. & Hindu & 171 \\
5. & Buddha & 400 \\
6. & Khonghucu & 8 \\
\hline
\end{tabular}

Sumber: Jawa tengah Dalam Angka, 2015

Mengutip data Jawa Tengah Dalam Angka tahun 2015 di atas, tampak jelas bahwa kota Salatiga cukup beragam dari sisi agama penduduknya. Para penyuluh agama Islam pun dihadapkan pada situasi demikian ini. Di beberapa wilayah di Salatiga, ditemukan adanya beragam rumah ibadah seperti masjid, gereja, dan vihara. Bahkan dalam satu kelurahan, ketiga rumah ibadah itu pun dapat berdiri, hal mana yang dapat ditemukan seperti di Kecamatan Argomulyo. Atas kondisi harmonis walau hidup dalam keberagaman seperti ini, layaklah Salatiga diganjar kota paling toleran tahun 2017.

Sampai penelitian lapangan dilakukan, diketahui bahwa lebih kurang 40 orang penyuluh Agama Islam, baik berstatus PNS maupun Non PNS di lingkungan Kementerian Agama Salatiga sejauh ini telah disibukkan dengan kegiatan kepenyuluhan keagamaan Islam di masyarakat Salatiga. Paling tidak, mereka berusaha memenuhi delapan dimensi kerja yang telah ditentukan, walaupun dalam realitasnya sulit ditemukan satu orang penyuluh memiliki dan mempraktikkan keseluruhan 8 (delapan) dimensi kerja.

Mendapatkan gelar kota toleran tentu menjadi beban berat termasuk bagi kalangan penyuluh agama Islam. Mereka harus diselaraskan dengan tingginya indeks kota toleran yang disematkan untuk kotanya. Karena itu, mereka yang tergabung dalam kepenyuluhan agama Islam, sebelum dinyatakan lolos seleksi di tahun 2017, dilihat betul latar belakangnya.

Jelasnya, rekruitmen penyuluh Agama Islam, terutama yang berstatus Non-PNS di Kota Salatiga dilaksanakan melalui seleksi yang cukup ketat dan diberikan skoring. Hal ini terutama pasca perubahan kebijakan yang memperkenalkan istilah Penyuluh Agama Non PNS, dan bukan lagi sekadar Penyuluh Agama Honorer (PAH). Dalam penjaringan dan penyaringan ini, para penyuluh Agama Islam yang berstatus PNS bergerak untuk menyosialisasikan kesempatan rekruitmen penyuluh agama Non PNS ini terutama kepada para muballigh dan muballigah di wilayah Salatiga yang telah berkiprah di masyarakat.

\section{Upaya Pemenuhan Delapan Dimensi Kepenyuluhan Agama Islam}

Sebagaimana dinyatakan di atas, para penyuluh agama Islam dalam mengupayakan terwujudnya religiusitas di masyarakat menyesuaikan dengan delapan spesialisasi yang diidealkan melekat pada kepenyuluhan sesuai SK Dirjen Bimas Islam No. 298 Tahun 2017. Sebenarnya hampir semua penyuluh menguasai materi keagamaan Islam yang mesti disampaikan kepada warga. Namun, kemampuan mereka ini dianggap tidak merata oleh otoritas kepenyuluhan Kemenag Salatiga (jajaran pimpinan Kelompok Kerja Penyuluh Pokjaluh) dan dari delapan spesialisasi itu, untuk wilayah Salatiga muncul beberapa figur penyuluh yang dianggap menonjol. Hampir semua sosok yang disebutkan di sini berstatus Non PNS.

Untuk spesialisasi Baca Tulis Alquran (BTA), muncul sosok seperti Husnul Kirom yang berkiprah di Pesantren Al Hasan, Sidorejo. Sudah lebih dari dua puluh tahun ia menggeluti pengajaran Alquran untuk anak-anak dan remaja, yang bukan hanya di pesantrennya, tetapi juga di beberapa tempat lain di Salatiga. la merupakan alumnus STAIN Salatiga. Terlahir di Kendal, sejak mahasiswa telah belajar di pesantren Al Hasan, yang kemudian diambil menantu oleh kyainya. Sekarang ini ia menjabat sebagai Ketua Badan Koordinasi (Badko) TPQ se-Salatiga. Sejak dulu ia memang mengambil konsentrasi di bidang seni baca Alquran (qori) dan pendidikan BTA. Untuk keperluan koordinasi tentang metode Iqro yang dipergunakan, ia kerap datang ke AMM, Kotagede, Yogyakarta. Selain itu, ia juga mengajarkan Kitab Tafsir Al Ibris kepada jamaah yaitu warga sekitar di pesantrennya. Selain itu, 
atas kiprahnya selama ini ia didaulat menjadi imam serta muazin di Masjid Raya Salatiga.

Sosok lain perlu disebut ialah Aminuddin yang menetap di Kawasan Blotongan Kecamatan Sidorejo. Rumahnya persis di sebelah Masjid Baiturridwan, Blotongan dan ia juga dipercaya sebagai takmir masjid tersebut. Dalam pembelajaran Alquran, ia menggunakan metode La Roiba Hanifida yang berpusat di Tebuireng, Jombang, Jawa Timur. la kebetulan memang alumni Pesantren Tebuireng, Jombang.

Selain itu, Aminuddin juga dianggap sosok penyuluh yang mumpuni dalam bidang produk halal. Menetap di Kampung Blotongan, berarti akrab dengan deretan warung sate. Benar juga, di sekitarnya menjamur warung sate dan gulai kambing Blotongan, area kuliner yang cukup terkenal di wilayah Salatiga menuju ke arah Semarang. Aminuddin seorang jagal bersertifikasi halal, atau yang lumrah disebut juru sembelih halal (juleha). Di tangannya, penyembelihan kambing tidak sampai 1 menit, atau hanya sekitar 40 detik. la terapkan penyembelihan kambing secara halal dengan mengikuti tuntunan fiqh. Selain niat yang tepat, ia juga mengetahui dan mampu menerapkan cara penyembelihan yang tidak menyiksa hewan. Karena itu, ia menjadi langganan pemotongan sapi maupun kambing para penjual sate di kawasan tersebut.

Lain halnya penyuluh Non PNS bernama Inayati yang dijumpai di Kawasan Ledok, Sidorejo yang menjadikan kediamannya sebagai tempat belajar Alquran dan diniyyah anak-anak di sore hari. Sore itu didapati banyak orangtua pengantar dan penjemput santri menunggu di halaman rumahnya yang luas. la menyatakan bahwa ia menggunakan Metode Yanbuu'a, mengacu pada metode yang dikembangkan dari alm KH. Arwani dari Kudus.

Inayati yang menamatkan sarjananya di IAIN Walisongo, Semarang tahun 2004 dan diangkat menjadi penyuluh non PNS sejak tahun 2018, juga membidangi isu radikalisme dan aliran sempalan. Selain secara rutin mengajarkan Alquran di TPQ dan RA di Kelurahan Ledok, ia juga aktif mengisi pengajian di kalangan lbu-lbu di wilayahnya. Salah satu pengajian yang diikuti penulis bersama penyuluh non PNS ini membahas tentang kerukunan umat beragama (KUB), yang disampaikan di depan kumpulan PKK, Kamis 10 Oktober 2019. Di perkumpulan PKK sore itu, setelah pembukaan Surat Fatihah, diteruskan dengan menyanyikan lagu Indonesia Raya, lalu pembacaan Pancasila, nyanyian mars PKK dan lalu pembacaan tahlil. Petugasnya pun berbeda-beda dan bergantian. Sore hari itu dihadiri 40-an jamaah perempuan yang semuanya berseragam gamis hijau kekuningkuningan. Inayati sebagai penceramah. Sore itu ia mengambil tema toleransi dalam bermuamalah, tetapi tidak bertoleransi dalam akidah. Dalam ceramahnya sore itu, ia menyinggung peristiwa penangkapan terduga teroris di kampung Ledok pertengahan tahun 2019 yang pelaku adalah pelarian dari Bekasi yang singgah ke rumah pamannya.

Dalam ceramahnya itu, Inayati juga menyinggung perihal muamalah, bertetangga, karena memang agamanya beragam tidak masalah dalam menjalin hubungan dan komunikasi dengan tetangga yang berbeda agama, termasuk dengan mereka yang beragama di luar Islam. Misalnya dalam hal antar mengantar makanan. Sebaggai Muslim tidak masalah menerima pemberian makanan dari tetangga yang berbeda agama. Hal itu justru menunjukkan toleransi dan kerja sama yang baik. Namun menurutnya, toleransi dan kerja sama tidak lagi boleh apabila sudah menyangkut akidah dan keimanan, masingmasing harus menjaga agar tidak terjadi kekacauan.

Penyuluh Agama Islam non PNS lain yang berkecimpung di bidang ini adalah Sidik yang merupakan alumnus sebuah pesantren di Bangil, Pasuruan, Jawa Timur. Ia selama ini aktif di ormas Anshor-Banser setempat dan menjadi Penyuluh Agama Islam honorer sejak tahun 2014. Lalu mengikuti tes rekruitmen kembali untuk penyuluh Non PNS tahun 2015 dan dinyatakan lolos.

Menetap di wilayah perbatasan antara Salatiga dan Semarang, jamaah yang dibinanya berada di kawasan plural dari sisi agama. Banyak tempat ibadah di desa wilayah ini seperti masjid, gereja dan vihara. Karena itu, ia pun tak segan-segan untuk turut hadir ketika diundang doa bersama di acara keagamaan Kristen maupun Buddha di kampungnya. la 
memilih masuk menjadi penyuluh pemerintah agar tidak dicurigai, terutama oleh kalangan ormas Islam yang lain yang juga telah mengembangkan dakwah di situ. la merintis berdirinya pengajian al Ikhlas di kelurahannya sejak tahun 2014. Jamaah kebanyakan perempuan, yang sebagian di antara mereka para buruh pabrik. la juga membimbing para muallaf di daerahnya (Wawancara dengan Sidik, penyuluh Agama Islam Non PNS Salatiga, 11 Oktober 2019).

Dalam bidang Kerukunan Umat Beragama (KUB), selain Inayati dan Sidik, dapat ditemukan seorang penyuluh non PNS yang bernama Sular yang bertugas di Kecamatan Sidorejo. Dalam waktu beberapa tahun belakangan, ia bergiat pada masalah penertiban rumah-rumah yang dijadikan kebaktian di wilayahnya. Alasannya karena untuk menjaga kota Salatiga yang toleran, maka rumah-rumah yang dijadikan tempat kebaktian itu ditutup, untuk menghindari protes dari masyarakat setempat. la menyatakan, kadang jamaah setempat hanya lima orang, tetapi jaamah dari luar wilayah justru lebih banyak.

Untuk dimensi keluarga sakinah, salah satu sosok penyuluh yang dipandang memiliki kecakapan di bidang ini bernama Nurcholis Majid (40). la dikenal seorang penceramah yang cukup andal dan kocak. Dua kali penulis mengikuti ceramahnya dan jamaah terpingkalpingkal dibuatnya. Sore hingga malam, Rabu, 8 Oktober 2019 itu, ia diminta mengisi pengajian di acara aqiqah anak dan selepas itu mengisi pengajian karyawan di Pabrik Singkong Keju D-9, di Ledok, Argomulyo, Salatiga. Di pengajian ini, ia menyampaikan materi tentang pemulasaraan jenazah. Alat peraga yang digunakan berupa boneka.

Di kawasan ini, masyarakat Muslim tinggal berdampingan dengan masyarakat Kristiani. Karena itu bagi dai dan penyuluh seperti Nurcholis Majid, walupun spesialisasinya keluarga sakinah, namun ia juga kerap menangani proses konversi ke Agama Islam, yang biasanya disebabkan proses pernikahan. Bahkan ada yang terlanjur mengandung, yang ternyata agama pasangan tersebut berbeda. Untuk pengesahan dan pengurusan sertifikat muallaf itu, ia bekerja sama dengan penyuluh agama PNS di KAU Argomulyo. Di
Kelurahannya, 2/3 penduduknya beragama Kristiani. Dalam setahun 2-3 peristiwa masuk Islam diprosesnya yang kebetulan ia juga dipercaya sebagai pejabat PPPN di Kelurahan Ledok. Selain itu, ia juga menjadi guru di Raudlatul Athfal (RA) Kelurahan Ledok. la sendiri mulai masuk menjadi Penyuluh Non PNS tahun 2016, melalui seleksi (Wawancara dengan Nurcholis Majid, penyuluh Agama Islam Non PNS Salatiga, 8 Oktober 2019).

Penyuluh lain yang concern pada masalah keimanan dan keluarga sakinah di wilayah Sidorejo bernama Musthofa Dasirun. Ia mendirikan dan membina TPQ Al Amien, Kampung Bancaan, Kelurahan Sidorejo Lor. la mengadakan kegiatan rutin berupa mujahadah setiap Rabu malam. Selain turut mendirikan TPQ Al Amien, ia juga aktif di kegiatan Badko TPQ Salatiga. Di lingkungannya mayoritas Kristiani, ia mengembangkan TPQnya untuk mengajar Alquran dan ilmu diniyyah terutama kepada anak-anak dan remaja. Dalam pengajaran Alquran, ia menggunakan metode Iqro. Karena berada di lingkungan plural, ketika pengajian dan mujahadah berlangsung, sound system yang digunakan hanya sound system dalam ruang. Sampai saat ini, di TPQ tersebut terdapat santri sore hari sebanyak 75 anak, sementara malam hari sebanyak 16 remaja.

Selain wilayah yang plural, lokasinya ini dengan dengan lokalisasi prostitusi di wilayah Salatiga. Sejauh ini, lokalisasi liar itu masih dibiarkan oleh pemkot, karena belum ada lokasi pengganti. Pertimbangannya juga belum ada alternative lapangan pekerjaan pengganti (Wawancara dengan Mudastir, Ketua Pokjaluh Salatiga, 11 Oktober 2019). Di kampung ini, masyarakatnya juga masih rata-rata abangan. Di tempat itu berdiri klinik Ananda yang telah dibeli oleh UKSW. Kini masih belum beroperasi, menunggu ijin dari pemerintah. Ekspansi UKSW ini bukan tidak mendapat reaksi dari penyuluh Agama Islam Non PNS seperti Musthofa (Wawancara tanggal 9 Oktober 2019).

Untuk spesialisasi bidang HIV/AIDS dan Narkoba, di Kecamatan Argomulyo dijumpai penyuluh Non PNS bernama Listyo Wati. la tercatat cukup rutin mengisi ceramah di pengajian anjangsana kalangan perempuan di Dusun Klampean, Kelurahan Noborejo, Kecamatan Argomulyo. Dalam ceramahnya, 
pada sebuah kegiatan kepenyuluhannya yang penulis ikuti pada tanggal 13 Oktober 2019, ia menggunakan Bahasa Indonesia sebagai Bahasa pengantarnya. Penguasaannya terhadap materi sangat bagus dan mendetail. Antara lain ia menyinggung adanya lokasi prostitusi di Kecamatan Sidorejo, yang dari situ kalangan pekerja seks komersial (PSK) paling rentan mengidap HIV/AIDS karena kegiatan seks bebas. Dijelaskannya, virus HIV/AIDS bersemayam di dalam sperma. la dapat tertular karena hubungan seks bebas. Penularan juga dapat melalui penggunaan jarum suntik dan penularan anak dari ibu yang mengidap HIV/AIDS.

Dalam ceramahnya itu, ia juga mengulas bahaya narkoba. la sampaikan narkoba pada mulanya ada untuk hal positif, misalnya untuk obat. Disebutnya tentang tanda lingkaran di obat-obat yang beredar di pasaran, yaitu biru (kandungan zat tinggi), hijau dan kuning. Sekarang obat bertanda biru sudah ditarik dari peredaran. Dulu ditemukan kasus anak-anak SMP di Salatiga membeli banyak obat bertanda biru ke sebuah warung setiap malam minggu. Pemilik warung curiga dan melaporkan ke perangkat. Setelah ditelusuri, ternyata obat itu dikonsumsi untuk nge-fly para remaja tersebut. Lalu setelah itu, di warung itu tidak lagi dijual obat-obatan jenis tersebut.

Sebagai penyuluh agama Islam sejak tahun 2011 di lingkungan Kemenag Kota Salatiga, khususnya di Kecamatan Argomulyo, Listyo Wati membina mengajian dan TPQ di wilayah Noborejo. Secara rutin, kegiatannya pada pagi hari mengajar di RA setempat, yang jumlah muridnya mencapai 100 lebih. la sendiri alumnus pesantren Al Barokah, Salatiga, dan kini tengah menyelesaikan studi $\mathrm{S}-1$ di Universitas Terbuka (UT).

la dapat merasakan dampak kepenyuluhan HIV/AIDS yang dijalaninya selama ini, angka ibu hamil yang bersedia memeriksakan kandungannya di 3 bulan pertama terutama di wilayahnya, cenderung meningkat. Sebelumnya diperoleh data dari sekitar 1.700 bumil di Salatiga, baru 700 yang bersedia memeriksakan di tiga bulan pertama.

Atas prestasinya dalam mengampanyekan bahaya HIV/AIDS dan juga Narkoba, ia diganjar penghargaan dari Dinas Kesehatan Provinsi
Jawa Tengah sebagai penyuluh teladan tingkat provinsi tahun 2018. la juga kerap diundang untuk memberikan penyuluhan tentang bahaya HIV/AIDS dan Narkoba di sekolah-sekolah dan instansi lainnya di wilayah Salatiga.

Selanjutnya, salah satu penyuluh non PNS di Kecamatan Argomulyo yang mengambil spesialisasi di bidang zakat dijumpai Abdul Syakur. la alumni sebuah pesantren di Kebumen dan kini tengah membina TPQ di desanya. Pada waktu penulis mengikuti pengajiannya, setelah sebelumnya dilakukan qodlo' sholat untuk seorang almarhumah jamaahnya, tema yang disampaikan mengenai fitrah dan zakat mal. la seorang penghafal Alquran, demikian pula istrinya.

Di Kecamatan Argomulyo pula, terdapat seorang penyuluh Non PNS yang dikenal sangat getol dan menguasai topik tentang wakaf. Bahkan ia turun tangan langsung jika ada pihak yang memintanya untuk menguruskan proses pencatatan wakaf. Makmur Haryono, 47 tahun, berasal dari Pare Kediri. la Pernah belajar di Pesantren Jampes dan Lirboyo. Kini ia membina majelis pengajian di Dusun Kembang, Kel. Randuajir. Wilayah ini penduduk beragam agama, bahkan keragaman agama itu terjadi dalam satu keluarga. Demikian dikonfirmasi oleh para jamaah pengajian yang dibinanya pada Kamis malam, 10 Oktober 2019 itu.

Diakuinya, sejauh ini telah menyelesaikan 20-an sertifikat tanah wakaf massal melalui program pendaftaran tanah sistematis lengkap (PTSL), yang dulu disebut juga Prona. Atas kiprahnya itu, ia pun menjadi tempat konsultasi wakaf bagi masyarakat di wilayah tersebut. Sebelumnya, ia pernah mengikuti sosialisasi UU wakaf di Kanwil Kemenag Jawa Tengah (Wawancara dengan Makmur Haryono, penyuluh Agama Islam Non PNS Salatiga, 8 Oktober 2019).

Penyuluh Agama Islam baik PNS mupun Non PNS dalam memperhatikan aspek religiusitas masyarakatnya, juga memperhatikan para napi narkoba yang berada di Lapas Kelas II Salatiga. Penulis diajak oleh Ketua Pokjaluh dan juga penyuluh agama Non PNS untuk melakukan pembinaan rohani kepada para napi di lapas tersebut. Pada suatu pagi di tengah penelitian lapangan, dilakukan kunjungan Ketua Pokjaluh disertai penyuluh 
Agama Non PNS atas nama Makmur Hariyono ke lapas tersebut. Pagi itu terjadwal pembinaan keagamaan berupa pembacaan salawat diba' dan barzanji dengan melibatkan para napi. Mengejutkan bahwa beberapa orang dari mereka lancar dan fasih membaca diba' maupun berzanji walaupun tanggannya penuh tato.

$\mathrm{Di}$ tengah kekaguman yang masih berlangsung itu, tiba-tiba dikagetkan oleh suara seorang sipir yang baru saja masuk ruangan aula itu bahwa sebentar lagi waktunya pemeriksaan urine bagi napi narkoba. Seperti terdengar bunyi petir di siang bolong, separuh dari jamaah siang itu, termasuk yang bagus bacaan diba' dan barzanji itu beranjak berdiri untuk mengikuti komando sipir tersebut. Penulis dan para penyuluh hanya mampu saling pandang saja.

\section{Manajemen Konversi Agama}

Menjadi penyuluh di wilayah plural, selain dimaksudkan untuk mengembangkan religiusitas di masyarakat dan juga berkaitan erat dengan toleransi antarwarga, ternyata membawa konsekuensi tersendiri. Hal ini karena terkait keunikan Salatiga. Bahwa di balik ganjaran predikat kota toleran, tersembul fenomena perpindahan agama di kalangan masyarakat.

Hal ini membuat para penyuluh di wilayah Salatiga untuk berinovasi agar proses konversi agama tersebut, bukan semata-mata berpindah agama, melainkan betul-betul bawa perpindahan agama itu disadari oleh palakunya. Sampai saat penelitian dilakukan, proses konversi itu telah diatur birokrasinya sedemikian rupa, sehingga sampai seorang muallaf harus harus mendapatkan sertifikat yang ditandatangani oleh Kepala Kantor Kemenag Salatiga.

Beberapa tahun sebelumnya, peristiwa konversi agama menjadi hal yang biasa saja. Umumnya konversi agama dilakukan menjelang pengikatan pernikahan. Kantor Urusan Agama (KUA) menjadi tempat paling mudah untuk pengurusan perpindahan agama, sekaligus pengikatan perkawinan. Namun, setelah pernyataan shadatain (dua kalimah syahadat) di KUA itu, banyak pasangan yang kembali ke agama asalnya. Muncul anggapan, bahwa Islam dianggap paling mudah sebagai tempat pengesahan perkawinan, hanya sebatas titik berangkat untuk mendapatkan dokumen keluarga seperti akte kelahiran, Kartu Keluarga (KK) dan setelah itu kembali ke agama semula. Belum ada regulasi yang mengikat saat itu, kecuali UU Perkawinan tahun 1974 yang menyatakan perkawinan sah jika dilakukan dengan pasangan seagama.

Hal ini menjadi keprihatinan para penghulu dan penyuluh agama Islam di wilayah Kota Salatiga. Diawali keheranan akan mudahnya proses perpindahan agama itu, maka dimulailah inovasi dengan perubahan pengurusan perpindahan agama. Setelah melalui proses beberapa tahun, sekarang tidak cukup hanya di KUA, hal yang membuat masyarakat tempat mereka tinggal tidak mengetahui perpindahan agama itu, tetapi harus dilampiri pernyataan kesediaan anggota keluarga, persetujuan RT, RW hingga lurah, barulah ke KUA dan disahkan Kakan Kemenag Salatiga. Tujuannya tidak lain agar perpindahan itu disaksikan masyarakat sekitar dan juga mengikat muallaf tersebut.

Persiapan menjelang pengucapan kalimat syahadat pun dilakukan dengan runtut, diawali bimbingan-bimbingan akidah dan syariat dasar yang diperlukan. Setelah cukup prosesnya, maka kemudian disahkan lewat persaksian pembacaan syahadat oleh penyuluh agama. Oleh sebabnya, para penyuluh agama Islam, PNS maupun non PNS, disibukkan dengan pembinaan baik sebelum dan setelah mereka menjadi muallaf. Para penyuluh dituntut untuk terus melakukan pembinaan akidah dan syariat kepada para muallaf itu. Beberapa kali dijumpai, karena di Salatiga terdapat sekolah maupun kampus tempat pembibitan menjadi calon pemimpin agama, terjadi perdebatan calon muallaf itu dengan penyuluh yang membimbing.

Jika para penyuluh membina sisi teologis, maka pembinaan ekonomi menjadi tanggung jawab Unit Pengelolaan Zakat (UPZ) Kemenag Salatiga dan Baznas Salatiga. Oleh Baznas Salatiga, para muallaf itu dibantu dengan pembinaan ekonomi produktif, bukan hanya sekadar diberikan uang dan perangkat ibadah. Mereka, para muallaf itu juga dipantau perkembangan ekonomi keluarganya setelah menjadi muallaf. Ini pun tidak jauh dari beberapa fakta, bahwa menjadi muallaf itu 
kerapkali terkucilkan dari keluarga dan juga rekan-rekan kerja dan bisnis sebelum memutuskan menjadi muallaf.

Hingga kini, program yang telah dimulai sejak sekitar tahun 2012 ini telah mencatatkan jumlah 1.290-an muallaf yang teradministrasi secara rapi di Kantor Kemenag Salatiga. Bagaimana yang Muslim berpindah ke agama lain? Ternyata pun ada. Pihak pokjaluh Salatiga masih merahasiakan data itu, yang sumbernya diperoleh dari Dinas Dukcapil Salatiga (Wawancara dengan Mudatsir, Ketua Pokjaluh Salatiga, 7 Oktober 2019).

\section{Penyuluh Agama Islam; Penopang Religiusitas dan Harmoni Warga}

Kedepalan dimensi kerja kepenyuluhan agama Islam di atas, dapat erat dikaitkan dengan upaya penguatan religiusitas masyarakat. Di sini, religiusitas masyarakat dimengerti bahwa masyarakat semakin mendalami ajaran agama dan mengamalkannya serta semakin tinggi tingkat kepuasan hidupnya (ten Kate et al., 2017). Indikator lainnya, masyarakat semakin rajin beribadah dan aktif berkegiatan di rumah ibadah. Hal-hal demikian ini menjadi kriteria yang dipahami secara luas tentang religiusitas.

Seperti halnya di wilayah lain, penyuluh agama Islam di Kota Salatiga juga telah berperan sejauh ini di di lingkungan masyarakat Muslim. Literasi mereka terhadap isu yang mereka sampaikan juga dapat dikatakan cukup mumpuni. Bagaimanapun, literasi para penyuluh ini sangat penting karena menjadi kekuatan kognisi mereka untuk melakukan pembinaan di masyarakat. Kognisi ini sangat ditentukan akan akses mereka terhadap literatur keagamaan yang tersedia (Eko Putro, 2020).

Para penyuluh agama Islam di Salatiga tersebar di empat kecamatan, yakni Kecamatan Sidorejo, Kecamatan Tingkir, Kecamatan Argomulyo, dan Kecamatan Sidomukti (Https://salatiga.go.id, n.d.). Di setiap kecamatan tersebut, masing-masing terdapat perwakilan kementerian Agama, atau yang populer dengan sebutan KUA (Kantor Urusan Agama). Di kantor ini, selain para penyuluh Agama Islam, juga berkantor penghulu pernikahan. Saat ini, jumlah penyuluh agama
Islam yang berstatus non PNS di Wilayah Kota Salatiga mencapai 32 orang dengan rincian 8 penyuluh Agama Islam Non PNS di setiap KUA. Adapun penyuluh PNS di setiap KUA berjumlah 2-3 orang.

Melihat kiprah dan peran penyuluh Agama Islam di lingkungan Kementerian Agama Salatiga dapat diketahui bahwa peran mereka cukup signifikan dalam mewujidkan religiusitas masyarakat yang dibina masing-masing penyuluh tersebut. Para penyuluh bukan semata memenuhi beban tugasnya melainkan juga mampu membaur dengan masyarakat yang menjadi dampingannya. Setidaknya, hal ini dapat dilihat dari setiap kegiatan yang diikuti penulis dengan mempertemukan penyuluh dengan masyarakat yang dibinanya. Dalam forum itu, para penyuluh tampak sangat dihormati dan mendapat tempat di hati jamaahnya dan selalu diberi waktu untuk menyampaikan nasihat-nasihat keagamaan.

Mereka juga turut menjaga kotanya sebagai kota toleran dengan mangatur perpindahan agama agar tidak menjadi masalah sosial. Apabila dikaitkan dengan proses dakwah, maka dakwah yang dibawakan para penyuluh agama Islam di Salatiga ini menyuguhkan bukan semata persoalan gerakan kesalehan berdasarkan anjuran agama, namun ternyata juga menyajikan jalinan kerjasama dan juga solusi untuk mencapai level kehidupan lebih baik, terutama untuk kalangan muallaf (Eko Putro \& Kosasih, 2018). Para muallaf juga didampingi, baik dalam hal penguatan pemahaman Islam maupun penguatan ekonomi keluarga.

Secara tersirat, kehadiran para penyuluh agama Islam tersebut juga memberikan kekuatan dan motivasi kepada para jamaah dalam menjalani kehidupan sehari-hari dengan pasti, jauh dari stress dan apalalagi jika mampu sampai menemukan kebahagiaan dalam hidupnya (religiousitas). Hal terakhir ini apabila meminjam hasil penelitian religiusitas dan kebahagiaan yang pernah dilakukan di Amerika Serikat. Seperti diungkap di bagian muka, Bergan and McConatha (2000) (Holdcroft, 2006) menyebutkan adanya relasi positif antara religiusitas dan kebahagiaan yang diperoleh dari studinya terhadap kelompok remaja, dewasa dan manula. Disimpulkan bahwa studi 
yang menguji tentang religiusitas dan kepuasan hidup (life satisfaction) pada tiga kelompok usia tersebut menyebutkan bahwa orang yang mengekspresikan dan terlibat secara kuat dalam bidang keagamaan kecil kemungkinan dilanda stress dan lebih besar peluang atas kepuasan hidupnya. Demikian pula keikutsertaan dan afiliasi pada kegiatan keagamaan.

Dikaitkan dengan tugas pokok dan fungsi (tupoksi) para Penyuluh Agama Islam Non PNS, paparan tentang definisi dan manfaat religiusitas di atas menemukan relevansinya jika dikaitkan untuk menjaga harmoni di masyarakat. Keharmonisan kehidupan sosial tentu saja tidak jauh dari nilai keagamaan, nilai-nilai religiusitas yang melekat pada masyarakatnya. Religiusitas masyarakat ini dalam hal ini dikembangkan oleh para penyuluh agama Islam Non PNS yang melekat pada Kementerian Agama. Maka, sejauh ini walaupun aspek happiness dan less stressful belum menjadi indikator utama yang digali dalam tulisan ini, baru sebatas religiusitas dan toleransi beragama, maka kiprah dan peran para penyuluh agama Islam Non PNS sungguh sangat signifikan.

\section{PENUTUP}

Sebagaimana disinggung di muka, bahwa SK Dirjen Bimas Islam No. 298 Tahun 2017 tentang Pedoman Penyuluh Agama Islam Non PNS telah dipraktikkan secara baik di Kota Salatiga. Namun diketahui bahwa tidak semua penyuluh memiliki kapasitas yang sama terhadap isu-isu dan bidang spesialisasi tersebut. Kedelapan spesialisasi itu yang masing-masing adalah Baca Tulis Alquran (BTA), produk halal, radikalisme dan aliran sempalan, keluarga sakinah, HIV/AIDS dan Narkoba, Zakat, Wakaf, dan Kerukunan Umat Beragama (KUB) telah dijalankan di Kota Salatiga.

Para penyuluh juga melakukan tupoksi kepenyuluhannya dengan metode yang cukup menarik, mulai dari penggunaan buku panduan, alat peraga hingga peralatan pengeras suara modern. Mereka juga disambut dan dihormati oleh para jamaahnya. Mereka menjadi bagian dari upaya perwujudan religiusitas di masyarakat. Para penyuluh Agama Islam terlah terbukti berperan untuk mengupayakan hal itu. Selain itu, khusus terkait dengan ciri khas Kota Salatiga yang plural dan toleran yang ternyata juga kerap terjadi konversi agama, peran penyuluh Agama Islam juga sangat jelas, memperkuat birokasi konversi agama itu, sehingga konversi agama bukan lagi sekadar pindah agama, melainkan menjadi kasadaran penuh bagi pelakunya (muallaf). Konversi agama juga menjadi masalah sosial yang mengkhawatirkan.

Dengan demikian, melalui terpenuhinya delapan dimensi kepenyuluhan Agama Islam oleh penyuluh agama Islam Non PNS di Salatiga, memberikan catatan penting bahwa peranan mereka tidak diragukan lagi dalam memperkuat religiusitas dan harmoni di masyarakat Salatiga. Apalagi di wilayah Salatiga yang plural masyarakatnya. Oleh karenanya, tidak berlebihan jika keberadaan mereka selayaknya terus diperhatikan dan ditingkatkan kesejahteraannya. 


\section{DAFTAR PUSTAKA}

Aliyah, S., \& Kusuma, B. M. A. (2019). Tuntutan Kinerja Dalam Keterancaman Kerja: Dilema Karir Penyuluh Agama Non Pegawai Negeri Sipil. Jurnal Ilmiah Syi'ar, 19(1), 55. https://doi.org/10.29300/syr.v19i1.2265

Aspers, P., \& Corte, U. (2019). What is Qualitative in Qualitative Research, (1), 139-160.

Basit, A. (2014). Tantangan profesi penyuluh agama islam dan pemberdayaannya. Jurnal Dakwah, XV(1), 157178. https://doi.org/https://doi.org/10.14421/jd.2014.15108

Eko Putro, Z. A. (2020). Pengayaan Literasi Keagamaan Melalui Akses Buku Keagamaan Penyuluh Agama Di Sulawesi Utara. Jurnal Lektur Keagamaan. https://doi.org/10.31291/jlk.v18i1.605

Eko Putro, Z. A., \& Kosasih, K. (2018). MEMBUKA KERAN KEMAJUAN DAN JARINGAN: GERAKAN DAKWAH LINTAS NEGARA (RI-PNG). Harmoni. https://doi.org/10.32488/harmoni.v17i1.221

Holdcroft, B. B. (2006). What is Religiosity. Journal of Catholic Education, 10(1), 89-103. https://doi.org/10.15365/joce.1001082013

Ilham. (2018). Peranan Penyuluh Agama Islam dalam Dakwah. Jurnal Alhadharah, 17(33), 49-80.

Kusnawan, A. (2011). Urgensi Penyuluh Agama. Jurnal Ilmu Dakwah, 5(17), 271-289.

Mawardi, M. (2017). KELUARGA SAKINAH: KONSEP \& POLA PEMBINAAN. International Journal Ihya' 'Ulum al-Din, 18(2), 253. https://doi.org/10.21580/ihya.17.2.1739

Menchik, J. (2014). Productive intolerance: Godly nationalism in Indonesia. Comparative Studies in Society and History, 56(3), 591-621. https://doi.org/10.1017/S0010417514000267

Mohajan, H. K. (2018). Qualitative Research Methodology in Social Sciences and Related Subjects. Journal of Economic Development, Environment and People, 7(85654), 23-48.

Munir, S. (2017). No TitleSalatiga Kembali Raih Predikat Kota Paling Toleran di Indonesia Artikel ini telah tayang di Kompas.com dengan judul "Salatiga Kembali Raih Predikat Kota Paling Toleran di Indonesia", https://regional.kompas.com/read/2017/11/20/12433971/salatiga-ke.

Noorbani, M. A. (2013). Penyelenggaraan Kepenyuluhan Agama Islam Non PNS di Kota Depok. Penamas Jurnal Penelitian Keagamaan dan Kemasyarakatan, 29, 2012-2013.

Olomojobi, Y. (2017). Explaining the Otmosis of Identity Threats and Religious Violence. SSRN Electronic Journal, 1-40. https://doi.org/10.2139/ssrn.3062534

Rosidin. (2017). Indeks Peran Penyuluh Agama dalam Membina Kehidupan Beragama Keluarga Majelis Taklim di Kabupaten Sragen, Jawa Tengah. Jurnal SMaRT Studi Masyarakat, Religi dan Tradisi Volume, 3(1). https://doi.org/DOl: http://dx.doi.org/10.18784/smart.v3i1.461.g291 INDEKS

Salleh, M. S. (2012). Religiosity in Development : A Theoretical Construct of an Islamic-Based Development. International Journal of Humanities and Social Science, 2(14), 266-274.

Sugiono, P. D. (2014). Metode penelitian pendidikan pendekatan kuantitatif.pdf. Metode Penelitian Pendidikan Pendekatan Kuantitatif, Kualitatif Dan R\&D.

Syuhudi, M. I. (2017). Penyuluh Agama dan Pengelolaan Kerukunan di Manado. Mimikri, 3(1), $28-41$.

ten Kate, J., de Koster, W., \& van der Waal, J. (2017). The Effect of Religiosity on Life Satisfaction in a Secularized Context: Assessing the Relevance of Believing and Belonging. Review of Religious Research, 59(2), 135-155. https://doi.org/10.1007/s13644-016-0282-1

Usman, A. H., Shaharuddin, S. A., \& Abidin, S. Z. (2017). Humanism in Islamic Education: Indonesian References. International Journal of Asia Pacific Studies, 13(1), 95-113. 